\title{
ESTROGEN AND VITAMIN D RECEPTORS GENES POLYMORPHISMS IN BREAST
} CANCER WOMEN

\author{
Magdy M. Ibrahim; Wael H. Elsawy*, Samy H.M. Ibrahim and Marwa H.S. Hussein \\ Medical Biochemistry and Clinical Oncology* Departments, Faculty of Medicine, Zagazig University
}

\begin{abstract}
Background: Estrogen receptor (ER) and vitamin D receptor (VDR) is a ligand-activated transcription factor that mediates estrogen and vitamin D actions in target tissues. Several common polymorphisms of the ER- agene and VDR gene have been reported to be associated with alterations in receptor expression and function. Objective: We evaluated the hypothesis that genetic polymorphisms in the PvuII restriction site of ER- $\alpha$ gene and FokI restriction site of VDR may be associated with breast cancer risk in Egyptian. Methods: In this study the involvement of two RFLPs, one at the ER- $\alpha$ gene locus, denoted as PvuII and the other at the VDR gene denotes as FokI in breast cancer were examined in 50 breast cancer cases and50 age frequency-matched controls. A case-control comparison was performed and the genotype distributions examined according to different tumor and population parameters. Result(s): PvuII polymorphism was associated with an increased risk of breast cancer $(\mathrm{OR}=1.9(0.755 .0), \mathrm{P}=0.01)$, while there was no significant difference in genotype frequency of the FokI polymorphism between controls and cases. In addition, significant association was found in patients with LN metastasis carrying the ER $-\alpha$ PvuII polymorphism. Also this study showed non-significant but generally higher relative risk of breast cancer for the $\mathrm{f}$ allele carriers of FokI polymorphism of Vitamin D receptors gene with breast cancer risk (OR $=2,65(1.5-5.2) \quad P=0.000)$. We did not find significant association between ERs gene PvuII res polymorphism and VDRs gene FokI polymorphism however there is significant association between the $\mathrm{f}$ allele and the $\mathrm{p}$ allele in cases $(\mathrm{P}=0.02)$. Conclusion(s): These results suggest that biomarkers for genetic polymorphisms could be used for the identification of breast cancer risk among Egyptian women.

Keywords: Breast cancer, estrogen receptor, polymorphism, vitamin d receptor
\end{abstract}

\section{INTRODUCTION}

B reast cancer is a common malignant disease in females and its incidence is increasing worldwide. It accounts for $22 \%$ of all female cancers. The estimated annual incidence of breast cancer worldwide is about one million case ${ }^{(\mathbf{1})}$.

There are several well-established risk factors for breast cancer and a variety of others currently under study ${ }^{(2)}$ such as family history, breast cancer susceptibility genes which are divided into 2 categories: 'the high-risk' breast cancer susceptibility genes including BRCA1, BRCA2, PTEN, TP53, LKB1/STK11 and CDH1 and the 'low to moderate-risk' breast cancer susceptibility genes CHEK2, TGF $\beta 1$, CASP8 and ATM genes ${ }^{(1)}$.

Other factors implicated are mammographic density ، ionizing radiation, histology of benign lesions 'diet, environmental agents, cigarette smoking, and estrogen replacement therapy ${ }^{(2)}$.

Estrogen plays a central role in the normal development of the mammary gland but is also involved in breast cancer progression ${ }^{(3)}$.

Genetic variation in genes involved in estrogen synthesis 'metabolism and signal transduction have been suggested to play a role in breast carcinoma. Estrogen exerts its biological effect through binding to estrogen receptors $(\mathrm{ERs})^{(4)}$, localized at the cytosolic and nuclear level. These receptors belong to the nuclear receptor hormone superfamily and are ligandinducible transcription factors. There are two types of estrogen receptors, the estrogen receptor$\alpha($ ER- $\alpha)$ and the estrogen receptor- $\beta($ ER- $\beta)$.

John et al. ${ }^{(5)}$ have found that vitamin $\mathrm{D}$ intake and serum concentrations of vitamin D metabolites inversely associated with risk for developing BC. $1,25(\mathrm{OH}) 2 \mathrm{D}$, the biologically most active form of vitamin $\mathrm{D}$, exerts its antiproliferative effects and modulate transcription of genes involved in cellular differentiation and cell growth by binding to vitamin D receptor (VDR). VDR is expressed in most cell types, including normal and malignant breast tissues.

The VDR gene is located on the long arm of chromosome 12 (12q12-14). It consists of at least five promoter regions, eight protein-coding exons, and six untranslated exons which are alternatively spliced. The Fok1 restriction enzyme identifies a polymorphic site in exon 2 at the 50 end of the VDR gene ${ }^{(6)}$.

Many subsequent molecular epidemiological studies were performed to assess the associations of VDR polymorphisms including Fok1, Bsm1, Apa1, and Taq1 with BC risk. 
However, the results were different or even contradictory. Single study may not have enough statistical power to detect dose-response relationships or even overall effects. Given the amount of accumulated data, a quantitative synthesis of the evidence was deemed important ${ }^{(7)}$.

In this article, we reported results from a case control study that examined the association of polymorphisms ER- $\alpha$ Pvul1 res. and VDR Fok1 res. with the risk of breast cancer

\section{PATIENTS AND METHODS}

Patients' Recruitment and Samples Collection: A case group of 50 breast cancer female patients were recruited consecutively for this study: The breast cancer patients were diagnosed at the Department of Oncology, Zagazig University, Egypt. The diagnosis was confirmed by histologic examination of malignant breast tissue. Detailed information on cancer diagnosis and treatment, including, tumor size, tumor grade, presence or absence of lymph node involved was obtained from medical records of these patients. The control group was randomly selected from the female general population with no history of any type of cancer. Controls were confirmed to be free from breast cancer by physical examination and mammography . Potential participants were approached. Those who consented were interviewed. All study subjects completed a structured questionnaire during an in person interview. A structured questionnaire was used to obtain information about age, body mass index, tobacco smoking habits, menstrual and reproductive history (including menopausal status age at menarche, parity, age at full term pregnancy and use of oral contraceptives) pathological diagnosis, age at diagnosis and family history of breast cancer in first and second degree relatives ‘ history of benign breast mass, history of diabetes mellitus and hypertension. Written informed consent was obtained from all tested subjects, and the study protocol was approved by relevant committees for the use of human subjects in research .

\section{DNA extraction:}

Blood was collected in a heparinzed vaccutainer from patients as well as controls. Genomic DNA was extracted from buffy coat fractions using the BioBasic DNA isolation kit (Bio Basic Inc. Ontario'Canada) following the manufacturer's protocol. Genotypic assay for Polymorphisms of both the estrogen receptor $\alpha$ Gene PvuII restriction site and VDR FokI restriction site. ER $\alpha$ and VDR genotyping were determined with PCR-RFLP. The DNA samples were all genotyped for the PvuII and fok1 restriction enzyme polymorphisms. The RFLPs were coded as P-p (PvuII) and F-f (FokI )upper case lettering signifying the absence, and the lower case lettering, the presence of the restriction site. For the PvuII of ERs The oligonucleotide primers utilized for our analysis were forward 5'CTGCCACCCTATCTGTATCTTT-3'and reverse-'5 'ACCCTGGCGTCGATTATCTGA-3'. The $50-\mu \mathrm{L}$ reaction mixture contained $25-\mu \mathrm{L}$ of master mix Promega), $0.2 \mathrm{mM}$ of each primer. 5 $\mu \mathrm{L}$ of DNA eluate was used for the reaction. After an initial denaturation at $94{ }^{\circ} \mathrm{C}$ for 5 minutes, 30 cycles $\left(94^{\circ} \mathrm{C}\right.$ for $1 \mathrm{~min}, 50{ }^{\circ} \mathrm{C}$ for $1 \mathrm{~min}$, and 72 ${ }^{\circ} \mathrm{C}$ for 90 seconds) were performed and were followed by a final 10 minute extension at $72{ }^{\circ} \mathrm{C}$ in a thermal cycler (Peqlab). The amplification products $(1.3 \mathrm{Kbp})$ were visualized by staining with ethidium bromide after electrophoresis on $1 \%$ agarose gel. All sets of PCRs included negative control samples containing no template DNA) for avoidance of PCR contaminant artifacts. (Fig.1a). The PCR products 'which contained a part of intron 1 and exon 2 of the ESR1 gene, were digested with PvuII (Fermentas) restriction enzymes at $37^{\circ} \mathrm{C}$ for 22 hrs . producing fragments of $1300 \mathrm{bp}$ (C allele $\mathrm{P}$ ) $450+850 \mathrm{bp}$ (T allele $\mathrm{p}$ ) and of 130, respectively. The DNA fragments were then separated using $1.5 \%$ agarose gel and detected by ethidium bromide staining (Fig1 b \&c. For the FokI restricion site of VDR The oligonucleotide primers and utilized for our analysis VDR2a: 5'AGCTGGCCCTGGCACTGACTCTGCTCT- 3' and VDR2b: 5'ATGGAAACACCTTGCTTCTTCTCCCTC- 3' PCR reaction was performed in a final volume of $25 \mu$ l that contained: $2 X$ PCR Mix: $12.5 \mu$ l. And Primer mix (100 pM): $4 \mu$ l. ,Genomic DNA: $5 \mu$ l. And Deionized water: $3.5 \mu$.

The amplification was carried out using thermal cycler PTC-100 machine (MJ Research, Inc., Watertown, Mass. USA) The amplification conditions were $94^{\circ} \mathrm{C}$ for $30 \mathrm{sec}, 60^{\circ} \mathrm{C}$ for $30 \mathrm{sec}$, and $72^{\circ} \mathrm{C}$ for $30 \mathrm{sec}$. A final elongation period of $5 \mathrm{~min}$ at $72^{\circ} \mathrm{C}$ was added after 30 cycles. PCR products were digested with $4 \mu \mathrm{L}$ Fokl and $5 \mu \mathrm{L}$ New England Biolabs buffer (Beverly, MA) for $1.5 \mathrm{hr}$ at $37^{\circ} \mathrm{C}$ and then electrophoresed through a $2 \%$ agarose gel for $2 \mathrm{hr}$ at $80 \mathrm{~V}$.

The $f$ genotype was indicated by the presence of the restriction site that generates two fragments of $196 \mathrm{bp}$ and $69 \mathrm{bp}$. The $F$ genotype was indicated by a single uncleaved 265- bp fragment. Determination of $V D R$ genotype $F F, F f$, 
or $f f$ was indicated based on the Fokl cleavage pattern. The DNA fragments were then separated using $1.5 \%$ agaros gel and detected by ethidium bromide staining Statistic Analysis. Chi-squared $(\chi 2)$ statistics were used to evaluate case control difference in the distribution of allele types and genotypes. Odds ratios (ORs) and 95\% confidence intervals (CIs), were used to measure the strength of the association between ER- $\alpha$ and VDR genes polymorphisms and breast cancer risk.

\section{RESULTS}

The distributions of clinical characteristics of the collected breast cancer cases are shown in (table 1).

Case patients with breast cancer and control subjects were comparable in age (mean age for cases $53.3 \pm 9.24$ years [range:36 - 68]). while in controls the mean age is $54.60 \pm 6.34$ [range:44 65]) table 2).

Allele frequencies of ER-agene PvuII polymorphisms in the control group showed that the $\mathrm{P}$ allele was more prevalent among controls
(0.55 (than cases (0.36) in the PvuII polymorphism (table 3 ).

Approximately $38 \%$ of controls and $24 \%$ of cases were carrying PP genotype, while $40 \%$ of controls and $48 \%$ of cases were carrying $\mathrm{Pp}$ genptype and $36 \%$ of cases and $14 \%$ of controls were carrying pp genotype (table 4).

There was no significant difference in genotype of the Fok I polymorphism of VDR gene between controls and cases however, Allele frequencies of VDR gene Fok1 polymorphisms in the control group showed that the $f$ allele was more prevalent among cases $(0.60$ (than controls (0.35) (table 5).

The assocciasion between FokI genotypes and PvuII genotypes in cases show no statistically significant relation between pp ,PP ,FF,ff,of Fok1 restriction site of VDR gene polymorphism and PvuII restriction site of ERS genepolymorphism. While between $\mathrm{Pp}$ and Ff there was statistically significant relationship (table 6).

Table (1): Characteristics of studied groups

\begin{tabular}{lcc}
\hline Characteristics & Group I & Group II \\
\hline - Family history of breast cancer & 2 & 17 \\
- Contraception & 6 & 4 \\
\hline
\end{tabular}

Table (2): Age in different studied groups

\begin{tabular}{ccc}
\hline Age & $\begin{array}{c}\text { Group I } \\
(\mathbf{n = 5 0})\end{array}$ & $\begin{array}{c}\text { Group II } \\
(\mathbf{n = 5 0})\end{array}$ \\
\hline Mean \pm SD & $53.3 \pm 9.24$ & $54.60 \pm 6.34$ \\
\hline Range & $36.0-68.0$ & $44.0-65.0$ \\
\hline
\end{tabular}

Table (3):Alleles of PVU11 of ERS gene polymorphisms in cases and controls:

\begin{tabular}{|c|c|c|c|c|c|c|c|}
\hline & $\begin{array}{l}\text { Allele of } \\
(\mathrm{N}=100)\end{array}$ & cases & $\begin{array}{l}\text { Allele } \\
\text { controls }\end{array}$ & $\begin{array}{r}\text { of } \\
\mathrm{N}=100)\end{array}$ & $\underline{x 2}$ & P-value & $\begin{array}{l}\text { OR } \\
(95.0 \% \mathrm{CI})\end{array}$ \\
\hline & No & $\%$ & No & $\%$ & & & \\
\hline $\mathbf{C}(\mathbf{P})$ & 36 & 36.0 & 55 & 55.0 & \multirow{2}{*}{7.3} & \multirow{2}{*}{$0.001 * * *$} & \multirow{2}{*}{$\begin{array}{c}0.5 \\
(0.25-0.84)\end{array}$} \\
\hline $\mathbf{T}(\mathbf{p})$ & 64 & 64.0 & 45 & 45.0 & & & \\
\hline
\end{tabular}

$* p<0.05$ when compared with control 
Table (4):Genotypes of ERsgene polymorphisms in cancer breast patients and controls :

\begin{tabular}{|c|c|c|c|c|c|c|}
\hline & \multirow[b]{2}{*}{ Genotypes } & \multicolumn{2}{|c|}{ grouping } & \multirow[b]{2}{*}{$X 2$} & \multirow[b]{2}{*}{ P-value } & \multirow[b]{2}{*}{ Odds ratio } \\
\hline & & $\begin{array}{c}\text { Cases } \\
(\mathbf{N}=50)\end{array}$ & $\begin{array}{c}\text { Controls } \\
(\mathbf{N}=\mathbf{5 0})\end{array}$ & & & \\
\hline \multirow[b]{2}{*}{$(\mathrm{C} / \mathrm{C}) \mathrm{PP}$} & Count & 12 & 19 & & & \\
\hline & $\%$ & $24.0 \%$ & $38.0 \%$ & 2.3 & 0.13 & $\begin{array}{c}0.3 \\
(01-0.8) \\
\end{array}$ \\
\hline \multirow[b]{2}{*}{$(\mathbf{C} / \mathbf{T}) \mathbf{P p}$} & Count & 24 & 20 & & & \\
\hline & $\%$ & $48.0 \%$ & $40.0 \%$ & 0.6 & 0.4 & $\begin{array}{c}1.4 \\
(0.58-3.3)\end{array}$ \\
\hline \multirow[b]{2}{*}{$(\mathbf{T} / \mathbf{T}) \mathbf{p p}$} & Count & 18 & 7 & & & \\
\hline & $\%$ & $36.0 \%$ & $14.0 \%$ & 6.4 & $0.01 * *$ & $\begin{array}{c}1.9 \\
(0.75-5.0)\end{array}$ \\
\hline
\end{tabular}

Table (5):Alleles of Fok1 of VDRgene in cases and controls:

\begin{tabular}{|c|c|c|c|c|c|c|c|}
\hline & \multicolumn{2}{|c|}{$\begin{array}{l}\text { Allele of cases } \\
\qquad(\mathrm{N}=\mathbf{1 0 0})\end{array}$} & \multicolumn{2}{|c|}{$\begin{array}{l}\text { Allele of controls } \\
(\mathrm{N}=\mathbf{1 0 0})\end{array}$} & \multirow{2}{*}{$\chi^{2}$} & \multirow{2}{*}{ P-value } & \multirow[t]{2}{*}{$\begin{array}{c}\text { OR } \\
(95.0 \% \mathrm{CI}) \\
\end{array}$} \\
\hline & No & $\%$ & No & $\%$ & & & \\
\hline $\mathbf{F}$ & 60 & 60.0 & 35 & 35.0 & \multirow{2}{*}{12.5} & \multirow{2}{*}{$0.000 * * *$} & 2.65 \\
\hline $\mathbf{F}$ & 40 & 40.0 & 65 & 65.0 & & & $(1.5-5.2)$ \\
\hline
\end{tabular}

${ }^{*} p<0.05$ when compared with control

Table (6):association between VDRgene polymorphisms and ERS genes polymorphisms in cancer breast patients:

\begin{tabular}{|c|c|c|c|c|c|c|c|}
\hline & & & \multicolumn{3}{|c|}{$\begin{array}{c}\text { Fok1 } \\
\text { cases }(\mathrm{N}=50)\end{array}$} & \multirow[t]{2}{*}{$\chi^{2}$} & \multirow{2}{*}{ P-value } \\
\hline & & & ff & Ff & FF & & \\
\hline \multirow{6}{*}{ PvuII } & $(\mathbf{T} / \mathrm{T})$ & Count & 7 & 7 & 5 & \multirow{6}{*}{16.5} & \multirow{6}{*}{$0.002 * *$} \\
\hline & pp & $\%$ & $77.8 \%$ & $31.8 \%$ & $26.3 \%$ & & \\
\hline & $(\mathbf{C} / \mathbf{T})$ & Count & 1 & 15 & 8 & & \\
\hline & Pp & $\%$ & $11.1 \%$ & $68.2 \%$ & $42.1 \%$ & & \\
\hline & $(\mathrm{C} / \mathrm{C})$ & Count & 1 & 0 & 6 & & \\
\hline & PP & $\%$ & $11.1 \%$ & $0.0 \%$ & $31.6 \%$ & & \\
\hline \multirow{2}{*}{\multicolumn{2}{|c|}{ Total }} & Count & 9 & 22 & 19 & & \\
\hline & & $\%$ & $100.0 \%$ & $100.0 \%$ & $100.0 \%$ & & \\
\hline
\end{tabular}

\section{DISCUSSION}

Worldwide, breast cancer comprises $10.4 \%$ of all cancer incidence among women, making it the second most common type of non-skin cancer (after lung cancer) and the fifth most common cause of cancer death. In 2004, breast cancer caused 519,000 deaths worldwide (7\% of cancer deaths; almost $1 \%$ of all deaths $)^{(8)}$.

In Egypt, it is the most common cancer among women, representing $18.9 \%$ of total cancer cases $^{(9)}$.

Most known risk factors for breast cancer can be linked to hazardous effects of hormonal exposures, although other risk factors such as female ( $1 \%$ male), aging, relative (mother or sister), menstrual history (early onset or late menopause), child birth after the age of 30 , exogenous estrogen, radiation exposure and obesity are also relevant in some populations ${ }^{(\mathbf{1 0})}$.

Approximately $15 \%$ of all breast cancer cases can be attributed to familial and genetic influences ${ }^{(11)}$.

Estrogen is implicated in the development of breast cancer, based on data from both clinical and animal studies; risk factors associated with breast cancer reflect cumulative exposure of the breast epithelium to estrogen ${ }^{(\mathbf{1 2})}$.

Two current hypotheses exist to explain this relationship. In the first, binding of estrogens to the ER stimulates proliferation of mammary 
cells, increasing the target cell number within the tissue, and the increase in cell division and DNA synthesis elevates the risk for replication errors, which may result in the acquisition of detrimental mutations that disrupt normal cellular processes such as apoptosis, cellular proliferation, or DNA repair $^{(13)}$.

In the second hypothesis, estrogen metabolism leads to the production of genotoxic by-products that could directly damage DNA, again resulting in point mutations. There is evidence that estrogen may act through both mechanisms to initiate and/or promote mammary cancer $^{(14)}$.

Currently, both SERMs and aromatase inhibitors are used in the treatment of breast cancer, and patients whose tumors are ER-positive respond well to these endocrine therapies. Further, both tamoxifen and raloxifene have proven effective as chemopreventative agents for breast cancer in high-risk women ${ }^{(\mathbf{1 5})}$.

The association of ER-genetic polymorphisms with breast cancer risk attracts much attention because ER functions as a hormone-dependent transcriptional regulator, which, in turn plays a significant role in the development of breast cancer ${ }^{(\mathbf{1 6})}$.

Several ER-gene polymorphisms have been reported Different biomarkers mapping estrogen receptor alpha have been associated with breast cancer risk. The most studied variants in this gene are the single nucleotide polymorphisms (SNPs) PvuII ( $\mathrm{C} / \mathrm{T}$ where $\mathrm{T}$ and $\mathrm{C}$ allele are often reported as $\mathrm{p}$ and $\mathrm{P}$ allele, present in intron 1 , $397^{(17)}$.

These variants have been implicated in gene expression by influencing transcription ${ }^{(\mathbf{1 8})}$.

Variation in the estrogen receptor gene PvuII has been associated with an increased risk of developing breast cancer ${ }^{(\mathbf{1 9})}$.

Previous studies investigating ER polymorphisms and breast cancer risk have produced mixed results, which may be explained by ethnicity of the populations under study. While some studies have found an increased risk for the $\mathrm{p}$ alleles of the PvuII polymorphisms, which agree with our study,' others have found an increased risk only for the $(\mathrm{P})$ allele ${ }^{(\mathbf{1 8 , 2 0 )} \text {. }}$

In addition, other studies found no effect at all for either of these polymorphisms ${ }^{(\mathbf{1 4})}$. In the present study, we found evidence of an association between ER- $\alpha$ PvuII polymorphism and Breast cancer risk.

Allele frequencies of ER-agene PvuII polymorphisms in the control group were similar to those reported previously from other studies conducted in Asian populations ${ }^{(18,20)}$.
Polymorphism at the PvuII restriction site ( $p$ allele) was associated with an elevated risk of breast cancer especially in young age. Two case studies showed that PvuII polymorphism was related to a younger age at breast cancer diagnosis ${ }^{(\mathbf{1 4})}$. We did not observed a similar, association, while other studies ${ }^{(\mathbf{1 4}, \mathbf{1 8})}$ also did not find this association.

PvuII polymorphisms are located in intron of theER-gene and are $50 \mathrm{bp}$ apart ${ }^{(14)}$.

Yaich et al. ${ }^{(\mathbf{1 4})}$ examined the PvuII polymorphism in the tumor tissue of 257 primary breast cancer patients and 140 peripheral blood DNA samples from women without breast cancer. Breast cancer patients with a pp genotype were significantly younger than women with PP or Pp genotype at the time of cancer diagnosis. In our case-control study, we found that the polymorphism at the PvuII restriction site $(\mathrm{p}$ allele) was associated with an elevated risk of breast cancer but not with exact group of age .

It would be useful to study the interaction of the ER-gene with genes involved in these pathways. In summary, in this population-based case-control study، we found that PvuII polymorphism in the ER-gene was associated with breast cancer risk. Additional studies are needed to understand the nature of the association .

The first study on breast cancer association with VDR polymorphisms was conducted by Ruggiero et al. in 1998. They found those women who carried bb homozygous had almost a four times higher risk of developing metastatic breast cancer compared with BB genotype carriers. Many subsequent molecular epidemiological studies were performed to assess the associations of VDR polymorphisms including Fok1, Bsm1, Apa1, Taq1 with breast cancer risk. However, the results were different or ever contradictory ${ }^{(21)}$.

In various observational studies, vitamin D intake and serum concentrations of vitamin D metabolites have been associated with decreased risk for developing breast cancer. Apart from the role that vitamin $\mathrm{D}$ plays in maintaining calcium homeostasis, its antiproliferative effects (by influencing cell differentiation, cell growth and apoptosis) are well established ${ }^{(22)}$.

Vitamin D from both diet and endogenous production is converted via two consecutive hydroxylation steps to 25-hydroxyvitamin D (25 $[\mathrm{OH}] \mathrm{D})$ and to 1,25-dihydroxyvitamin D $(1,25[\mathrm{OH}] 2 \mathrm{D})$. The biologically most active form of vitamin $\mathrm{D}$ is $1,25(\mathrm{OH}) 2 \mathrm{D}$, which mainly exerts its antiproliferative effects by binding to the vitamin D receptor (VDR) and acting in complex as a transcriptional factor for a variety of genes, 
including those involved in cell differentiation and cell growth ${ }^{(23)}$.

The VDR is present in a variety of cell types, including malignant and normal breast cells. Various studies have assessed associations between various polymorphisms in the VDR gene and breast cancer risk, with inconsistent results. These polymorphisms include three frequently analyzed, highly linked single nucleotide polymorphisms (SNPs) FokI, BsmI, ApaI and TaqI at the $3^{\prime}$ end of the VDR gene ${ }^{(24)}$.

13 papers have analysed the association of FokI with breast cancer risk ${ }^{(21,25,26,27,28,29)}$ are reporting non-significant but generally higher relative risk of breast cancer for the $f$ allele carriers which agree with our study.

Three other studies ${ }^{(30,31,32)}$ did not observe any association.

While Sinotte et al. ${ }^{(24)}$; Chen et al. ${ }^{(33)}$; Gapska et al. ${ }^{(34)}$; Tang et al. ${ }^{(35)}$ and Raimondi et al. ${ }^{(36)}$ showed a statistically significant increase in relative risk of breast cancer in women with ff genotype compared with women with the FF genotype). Moreover, these studies suggest that relative risk of breast cancer increases with the increasing dosage of the f allele. If our observed associations are valid and causal, about 13 and $25 \%$ of the incidence rate of breast cancer in $\mathrm{Ff}$ and ff carrier would be attributable to their respective FokI genotypes

TheFokI polymorphism is located at exon 2 start codon of the VDR gene. Individuals designated $F$ have VDR proteins missing three amino acids (424 amino acids) and those designated $\mathrm{f}$ have longer VDR proteins 427 amino acids) that have been shown to be functionally less efficient ${ }^{(37)}$.

Since $\mathrm{f}$ allele results in a less efficient VDR, the increase in breast cancer incidence associated with $\mathrm{f}$ allele could possibly be overturned, or at least reduced، by raising vitamin D levels, for instance through vitamin D supplementation. Interaction between VDR FokI SNP and vitamin D has been recently observed for prostate cancer $^{(38)}$.

We did not find significant association between ERs gene pvu11 res polymorphism and VDRs gene fok1 res polymorphism however there is association between the $f$ allele and the $p$ allele in cases .

More studies should be done to examine the association between the polymorphisms in the steroid receptors genes especially in breast cancer patients.

\section{CONCLUSION}

Our study also showed a significant association between ER- $\alpha$ PvuII polymorphism and risk of cancer breast .

Also this study showed non-significant but generally higher relative risk of breast cancer for the $f$ allele carriers of FokI with breast cancer risk .

We did not find significant association between ERs gene PvuII res polymorphism and VDRs gene FokI res polymorphism however there is association between the f allele and the $p$ allele in cases .

\section{REFERENCES}

1- Oldenburg RA, Meijers HH, Heijboer H, Cornelisse CJ and Devilee P. Genetic susceptibility for breast cancer: How many more genes to be found? Critical Reviews in Oncology / Hematology 2007; 63(2): 49-125.

2- Hulka BS, Moorman PG. Breast cancer : hormones and other risk factors. Maturitas 2001; 38: 103-16.

3- $\quad$ Maguire P, Margolin S, Skoglund J, Sun XF, Gustafsson JA, Borresen-Dale AL and Lindblom A. Estrogen receptor beta (ESR2) polymorphisms in familial and sporadic breast cancer. Breast Cancer Res Treat 2005; 94 (2): 145-52 .

4- Roodi N, Bailey LR, Kao WY, Verrier CS, Yee CJ, Dupont WD, Parl FF. Estrogen receptor gene analysis in estrogen receptor-positive and receptornegative primary breast cancer. J Natl Cancer Inst 1995; 87 (6): 446-51.

5- John EM, Phipps AI, Knight JA, Milne RL, Dite GS and Hopper JL. Medical radiation exposure and breast cancer risk: findings from the Breast Cancer Family Registry. Int J Cancer 2007; 121: 386-394.

6- Townsend K, Banwell CM, Guy M, Colston KW, Mansi JL, Stewart PM, Campbell MJ and Hewison M. Autocrine metabolism of vitamin D in normal and malignant breast tissue 2007; 231: 35793586.

7- Guy M, Lowe LC, Bretherton-Watt D, Mansi JL and Colston KW. Approaches to evaluating the association of vitamin $\mathrm{D}$ receptor gene polymorphisms with breast cancer risk. Cancer Res 2002; 164: 43-54.

8- Park S, Koo J, Kim JH, Yang WI, Park BW and Lee KS. Clinicopathological characteristics of mucinous carcinoma of the breast in Korea: comparison with invasive ductal carcinoma-not otherwise 
specified. J Korean Med Sci 2010; 25(3): 361-368.

9- Omar S, Khaled H, Gaafar R, Zekry AR, Eissa $\mathrm{S}$ and El-Khatib O. Breast cancer in Egypt: a review of disease presentation and detection strategies. East Mediterr Health J 2003; 9(3): 448-463.

10- Roncker S, vanEtten E and Mathieu C. Immunoregulation by 1,25dihydroxyvitamin D3: basic concepts. J Steroid Biochem Mol Biol 2005; 97: 93101.

11- Saslow D, Boetes C, Burke W, Harms S, Leach MO, Lehman CD. American Cancer Society guidelines for breast screening with MRI as an adjunct to mammography. CA Cancer J Clin 2007; 57:75-89.

12- $\mathrm{Wu} \mathrm{H}$, et al. Hypomethylation-linked activation of PAX2 mediates tamoxifenstimulated endometrial carcinogenesis. Nature 2005; 438: 981-987.

13- Herrmann BL. Impact of estrogen replacement therapy in a male with congenital aromatase deficiency caused by a novel mutation in the CYP19 gene. J Clin Endocrinol Metab 2002; 87: 54765484.

14- Yaich L, Dupont WD, Cavener DR and Parl FF. Analysis of the PvuII restriction fragment-length polymorphism and exon structure of the estrogen receptor gene in breast cancer and peripheral blood. Cancer Res 1992; 52: 77-83.

15- Bocchinfuso WP and Korach, KS. Mammary gland development and tumorigenesis in estrogen receptor knockout mice. J Mammary Gland Biol Neoplasia 1997; 2: 323-334.

16- Kamangar F, Dores G and Anderson W. Patterns of cancer incidence, mortality, and prevalence across five continents: defining priorities to reduce cancer disparities in different geographic regions of the world. J Clin Oncol 2006; 24: 2137 50 .

17- Wang J, Higuchi R, Modugno F, Li J, Umblas N, Lee J, Lui LY, Ziv E, Tice JA and Cummings SR. Estrogen receptor alpha haplotypes and breast cancer risk in older Caucasian women. Breast Cancer Res Treat 2007; 106 (2): 273-80.

18- Cai Q, Shu XO, Jin F, Dai Q, Wen W, Cheng JR, Gao YT, Zheng W. Genetic polymorphisms in the estrogen receptor alpha gene and risk of breast cancer: results from the Shanghai Breast Cancer
Study. Cancer Epidemiol Biomarkers Prev 2003; 12(9): 853-9.

19- Gonzalez - Mancha R, Galan JJ, Crespo C, Iglesias Perez L, Gonzalez - Perez A, Moron FJ, Moreno Nogueira JA, Real LM, Pascual MH and Ruiz A. Analysis of the ER alpha germline 840 Estrogen Receptor Polymorphism and Breast Cancer. AA Saad et al. Bull. Alex. Med Sci Monit 2008; 14 (3): CR136-43.

20- Shin A, Kang D, Nishio H, Lee MJ, Park SK, Kim SU, Noh DY, Choe KJ, Ahn SH and Hirvonen A. Estrogen receptor alpha gene polymorphisms and breast cancer risk. Breast Cancer Res Treat 2003; 80 (1): $127-31$.

21- Guy M, Lowe LC, Bretherton-Watt D, Mansi JL and Peckitt C. Vitamin D receptor gene polymorphisms and breast cancer risk. Clin Cancer Res 2004; 10 : 5472-81.

22- Goodwin PJ, Ennis M, Pritchard KI, Koo J and Hood N. Prognostic effects of 25hydroxyvitamin $\mathrm{D}$ levels in early breast cancer. J Clin Oncol 2009; 27: 3757.

23- Trabert B, Malone KE, Daling JR, Doody DR and Bernstein L. Vitamin D receptor polymorphisms and breast cancer risk in a large population-based case-control study of Caucasian and African-American women. Breast Cancer Res 2007; 9: R84.

24- Sinotte M, Rousseau F, Ayotte P, Dewailly E and Diorio C. Vitamin D receptor polymorphisms (FokI, BsmI) and breast cancer risk: association replication in two case-control studies within French Canadian population. Endocrine-Related Cancer 2008; 15: 975-983.

25- Bretherton-Watt D, Given-Wilson R, Mansi JL, Thomas V and Carter N. Vitamin D receptor gene polymorphisms are associated with breast cancer risk in a UK Caucasian population. $\mathrm{Br} \mathrm{J}$ Cancer 2001; 85: 171-5.

26- John EM, Phipps AI, Knight JA, Milne RL, Dite GS and Hopper JL. Medical radiation exposure and breast cancer risk: findings from the Breast Cancer Family Registry. Int J Cancer 2007; 121: 386-394.

27- Abbas S, Nieters A, Linseisen J, Slanger T and Kropp S. Vitamin D receptor gene polymorphisms and haplotypes and postmenopausal breast cancer risk. Breast Cancer Res 2008; 10: R31.

28- McKay JD, McCullough ML, Ziegler RG, Kraft $\mathrm{P}$ and Saltzman BS. Vitamin D receptor polymorphisms and breast cancer 
risk: results from the national cancer institute breast and prostate cancer cohort consortium. Cancer Epidemiol Biomarkers Prev 2009; 18: 297-305.

29- Rollison DE, Cole AL, Tung KH, Slattery ML and Baumgartner KB. Vitamin D intake, vitamin $\mathrm{D}$ receptor polymorphisms, and breast cancer risk among women living in the southwestern U.S. Breast Cancer Res Treat 2012; 132(2): 683-91.

30- Curran JE, Vaughan T, Lea RA, Weinstein SR and Morrison NA. Association of A vitamin $\mathrm{D}$ receptor polymorphism with sporadic breast cancer development. Int $\mathbf{J}$ Cancer 1999; 83: 723-6.

31- Ingles SA, Garcia DG, Wang W, Nieters $\mathrm{A}$ and Henderson BE. Vitamin D receptor genotype and breast cancer in Latinas (United States). Cancer Causes Control 2000; 11: 25-30.

32- McCullough ML, Stevens VL, Diver WR, Feigelson HS and Rodriguez C. Vitamin D pathway gene polymorphisms, diet, and risk of postmenopausal breast cancer: a nested case-control study. Breast Cancer Res 2007; 9: R9.

33- Chen WY, Bertone-Juhnson ER, Hunter DJ, Willett WC and Hankinson SE. Associations between polymorphisms in the Vitamin D receptor and breast cancer risk. Cancer Epidemiol Biomarkers Prev 2005; 14: 2335-9.

34- Gapska P, Scott RJ, Serrano-Fernandez P, Huzarski $\mathrm{T}$ and Byrski T. Vitamin D receptor variants and breast cancer risk in the Polish population. Breast Cancer Res Treat 2009; 115: 629-33.

35- Tang C, Chen N, Wu M, Yuan H and Du Y. FokI polymorphism of vitamin D receptor gene contributes to breast cancer susceptibility: a meta-analysis. Breast Cancer Res Treat 2009; 117: 391-399.

36- Raimondi S, Johansson H, Maisonneuve P and Gandini S. Review and meta-analysis on vitamin $\mathrm{D}$ receptor polymorphisms and cancer risk. Carcinogenesis 2009; 30: 1170-1180.

37- Uitterlinden AG, Fang Y, van Meurs JB, Pols HA and Van Leeuwen JP. Genetics and biology of vitamin $\mathrm{D}$ receptor polymorphisms. Gene 2004; 338: 143156.

38- Li C, Li Y, Gao LB, Wang YY, Zhou B, Lv ML, Lu HM, and Zhang L. Vitamin D receptor gene polymorphisms and the risk of colorectal cancer in a Chinese population. Dig Dis Sci 2009; 54: 634639. 
التباين الجيني لكل من جيني مستقبلات الاستروجين

وفيتامين د لسرطان الثذي في النساء مناء الأبترو

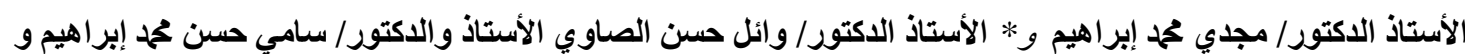

الطبيبه/ مروه حسن سليمان حسين والن حسن الصنين

$$
\text { قسم الكبيباء الحبيوية الطبية و* قسم علاج الأورام }
$$

يعتبر سرطان الثذي أكثر أنواع الأور ام الخبيثة انتشار ا في السيدات ، هناك العديد من العو امل التي يعتقد أنها تساعد على حدوث هذا

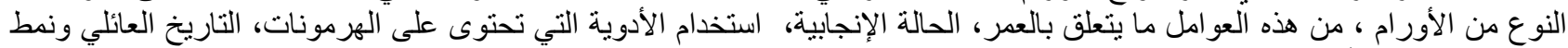

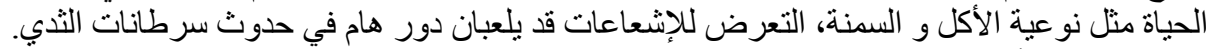

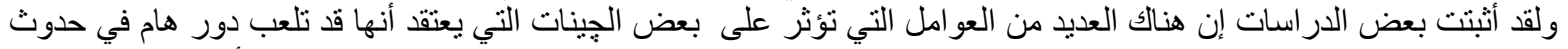

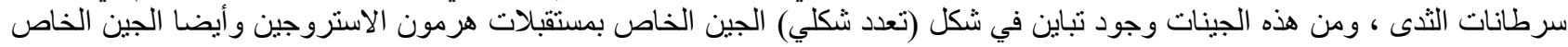
بمستقبلات فيتامين (د).

الاهدف من البحث : إيضاح دور التباين الجينى لكل من الجين الخاص بمستقبلات فيتامين د ومستقبلات هرمون الاستروجين فى التطور

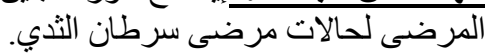

المرضى وطرق البحث: تمت هذه الدر اسة فى قسمي الكيمياء الحيوية والبيولوجيا الجزيئية والأورام بكلية الطب جامعة الزقازيق.

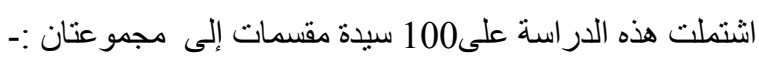

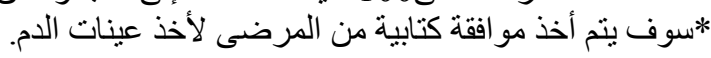
المجموعة الأولى : تشمل 50 سيدة أصحاء لا يعانون من سرطان الثذي كمجمو عة ضابطة.

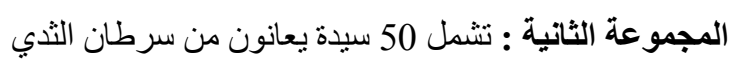
تبين من البجه البحث:

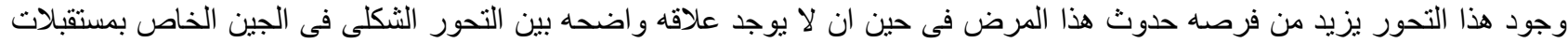

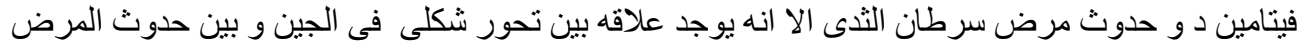

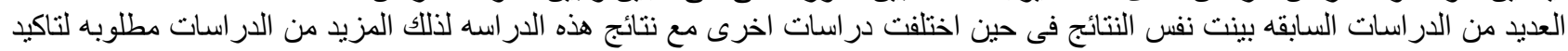

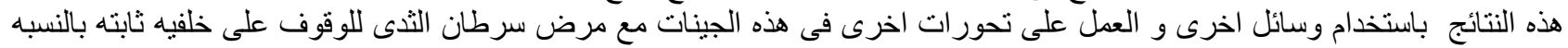
لعلاقه هذا المرض مع التباين الجينى في هذين الجنى الجينين. 